\title{
miR-20b inhibits the senescence of human umbilical vein endothelial cells through regulating the Wnt/ $\beta$-catenin pathway via the TXNIP/NLRP3 axis
}

\author{
FEIFEI DONG, SHAOHUA DONG, YING LIANG, KE WANG, YONGWEN QIN and XIANXIAN ZHAO \\ Department of Cardiology, Changhai Hospital, Shanghai 200433, P.R. China
}

Received June 26, 2019; Accepted November 13, 2019

DOI: $10.3892 /$ ijmm.2020.4457

\begin{abstract}
Endothelial cell senescence is closely related to the occurrence of cardiovascular diseases and microRNAs (miRNAs/miRs) are considered as therapeutic targets for cardiovascular disease. The current study aimed to investigate the role of miR-20b in the senescence process of endothelial cells and its underlying mechanism. Cell viability, proportion of senescent cells and the cell cycle were respectively determined by Cell Counting Kit- 8 , SA- $\beta$-galactosidase and flow cytometry. The relative expressions of mRNA and protein were detected by reverse transcription-quantitative polymerase chain reaction and western blotting, respectively. The possible target genes and binding sites of miR-20b were predicted using Targetscan and further verified by dual luciferase reporter assay. The present study found that $\mathrm{H}_{2} \mathrm{O}_{2}$ inhibited cell viability, caused cell cycle arrest in $\mathrm{G} 1$ phase, decreased miR-20b level and induced cell senescence. Moreover, high expression of miR-20b promoted cell viability and reduced $\mathrm{H}_{2} \mathrm{O}_{2}$-induced cell senescence, whereas low expression of miR-20b produced the opposite effects. Thioredoxin interacting protein (TXNIP) was predicted as a target gene for miR-20b and knockdown of TXNIP increased cell viability, inhibited cell senescence, reduced the expression of p16, p21, TXNIP, NLR family pyrin domain containing 3 (NLRP3) and cleaved Caspase-1 and reversed the promoting effects of the miR-20b inhibitor and $\mathrm{H}_{2} \mathrm{O}_{2}$ on cell senescence. Furthermore, the knockdown of TXNIP inhibited the Wnt/ $\beta$-catenin pathway. The finding reveals that high expression of miR-20b inhibits the senescence of human umbilical vein endothelial cells through regulating the $\mathrm{Wnt} / \beta$-catenin pathway via the TXNIP/NLRP3 axis.
\end{abstract}

Correspondence to: Dr Xianxian Zhao, Department of Cardiology, Changhai Hospital, 168 Changhai Road, Yangpu, Shanghai 200433, P.R. China

E-mail: xianxzh_zhao@163.com

Key words: microRNA-20b, cellular senescence, thioredoxin interacting protein/NLR family pyrin domain containing 3 axis, Wnt/ $\beta$-catenin pathway, endothelial cell

\section{Introduction}

Population aging is one of the main problems facing the 21st century. Aging is associated with an increased incidence of age-related diseases such as Parkinson's, Alzheimer's, cardiovascular and other diseases (1). Cardiovascular disease is a chronic disease closely related to aging (2) and atherosclerosis is the primary cause of cardiovascular disease. As we age, the structure and function of artery vasculature changes, the vessel lumen expands, vascular stiffness increases, eventually affecting other tissues and organs (3). Noticeably, the damage and functional changes of vascular endothelial cells play a crucial role in the occurrence and development of atherosclerosis, and penetrate into the whole pathological process of atherosclerosis (4).

Vascular endothelial cells, which are monolayer squamous epithelial cells located between vascular endothelium subcutaneous tissues and blood, function as a physical barrier between blood and tissues. Vascular endothelial cells play an important role in maintaining normal vascular function and tissue structure and in the regulation of cells proliferation $(5,6)$. Endothelial cell senescence, which is closely related to atherosclerosis, is accompanied by the destruction of endothelial cell integrity and functional damage of endothelial cells that in turn cause vascular dysfunction, therefore creating conditions for the occurrence of cardiovascular diseases $(7,8)$. Thus, it is highly necessary to understand the mechanism of endothelial cell senescence, to provide patients with effective clinical treatment and reduce the occurrence of cardiovascular diseases.

MicroRNAs (miRNAs/miRs) are small non-coding RNAs and have been regarded as therapeutic targets and biomarkers for evaluating cardiovascular disease in recent years (9). Among miRNAs, miR-222-221 can inhibit the proliferation and migration of endothelial cells and induce apoptosis $(10,11)$. miR-126-3p and miR-126-5p are considered as potential biomarkers of atherosclerosis (12). A recent study reported that miR-20b is up-regulated in insulin-resistant skeletal muscle and is involved in glucose metabolism regulation (13). Moreover, miR-20b has been shown to play a critical role in maintaining vascular integrity, as the down-regulation of miR-20b was found to be able to down-regulate the level of a cellular senescence marker (14). However, studies are still needed to confirm the role and mechanism of miR-20b 
in endothelial cell senescence. In this study, the occurrence of senescence of HUVECs cells was induced by hydrogen peroxide $\left(\mathrm{H}_{2} \mathrm{O}_{2}\right)$ and the role of miR-20b in the process of cellular senescence and its possible mechanism were investigated.

\section{Materials and methods}

Cellculture.Human umbilical vein endothelial cells (HUVECs) were purchased from Sciencell Research Laboratories, Inc., (cat. no. 8000). The cells were cultured in the endothelium cell medium (Sciencell Research Laboratories, Inc.) containing $5 \%$ fetal bovine serum (Sigma-Aldrich; Merck KGaA), $1 \%$ endothelial growth factor (Sigma-Aldrich; Merck KGaA), $100 \mu \mathrm{g} / \mathrm{ml}$ streptomycin (Gibco; Thermo Fisher Scientific, Inc.) and $100 \mathrm{U} / \mathrm{ml}$ penicillin (Gibco; Thermo Fisher Scientific, Inc.) in an incubator with $95 \% \mathrm{O}_{2}$ and $5 \% \mathrm{CO}_{2}$ at $37^{\circ} \mathrm{C}$.

Induction of HUVECs cell senescence by $\mathrm{H}_{2} \mathrm{O}_{2} \cdot \mathrm{H}_{2} \mathrm{O}_{2}$ was used to stimulate and induce cell senescence in HUVECs. The cells were randomly divided into 5 groups and treated with different concentrations of $\mathrm{H}_{2} \mathrm{O}_{2}(0,10,50,100$ and $500 \mu \mathrm{M})$. The blank group $\left(0 \mu \mathrm{M} \mathrm{H}_{2} \mathrm{O}_{2}\right)$ was cultured in normal medium, whereas the $\mathrm{H}_{2} \mathrm{O}_{2}$ group was incubated with normal medium at different concentrations of $\mathrm{H}_{2} \mathrm{O}_{2}$ for $24 \mathrm{~h}$. The cell viability, proportion of senescent cells and cell cycle in each group were determined by Cell-Counting-Kit 8 (CCK-8; Beyotime Institute of Biotechnology), SA- $\beta$-galactosidase (SA- $\beta$-gal; Beyotime Institute of Biotechnology) and FACSCalibur Flow Cytometer (cat. no. 342973; BD Biosciences; Becton, Dickinson and Company).

Transfection. The specific groups were: Scramble group, miR-20b mimic group, miR-20b inhibitor group, scramble $+\mathrm{H}_{2} \mathrm{O}_{2}$ group, miR-20b mimic $+\mathrm{H}_{2} \mathrm{O}_{2}$ group and miR-20b inhibitor $+\mathrm{H}_{2} \mathrm{O}_{2}$ group. The sequences required for transfection are shown in Table I. The cells were transfected with the miR-20b mimic (100 pmol), miR-20b inhibitor (100 pmol) or 100 pmol scramble (Sigma-Aldrich; Merck KGaA) using Lipofectamine 2000 Transfection Reagent (Invitrogen; Thermo fisher Scientific, Inc.). Next, the Lipofectamine 2000 reagent was mixed with DMEM and incubated with the cells for $24 \mathrm{~h}$ at $37^{\circ} \mathrm{C}$ with $5 \% \mathrm{CO}_{2}$. After that, the medium was replaced and certain groups of cells were stimulated by $\mathrm{H}_{2} \mathrm{O}_{2}$ $(100 \mu \mathrm{M})$ for $24 \mathrm{~h}$, while the rest was left untreated. The Scramble served as a negative control and whether the transfection was successful was confirmed by performing reverse transcription-quantitative (RT-q)PCR.

Knocking down thioredoxin interacting protein (TXNIP) using small interfering RNA (siRNA). TXNIP was knocked down by siRNA (Forward, RNA oligo: 5'-AGAGAAAAAGCC UUCUUUCCC-3', and reverse, RNA oligo: 5'-GAAAGAAGG CUUUUUCUCUGA-3', GE Healthcare Dharmacon Inc.) and a non-specific siRNA served as a negative control (NC sense RNA oligo: 5'-AGAAUCACUGUACAUCAACUCUA-3', antisense RNA oligo: 5'-GAGUUGAUGUACAGUGAUUCU GC-3'). The HUVECs cells were transfected with siTXNIP (100 pmol) by Lipofectamine 2000 Transfection Reagent, at the same time, the cells incubated with Lipofectamine 2000 only were used as blank control group. Whether the transfection was successful was confirmed by performing RT-qPCR.

Next, the cells were co-transfected with miR-20b inhibitor $(100 \mathrm{pmol})$ and siTXNIP (100 pmol) or NC, with NC group served as the control group. Some of the cells were stimulated by $\mathrm{H}_{2} \mathrm{O}_{2}(100 \mu \mathrm{M})$ for $24 \mathrm{~h}$, while the rest was left untreated. The specific groups were as follows: NC group, siTXNIP miR-20b inhibitor $+\mathrm{NC}$ group, miR-20b inhibitor + siTXNIP group, miR-20b inhibitor $+\mathrm{H}_{2} \mathrm{O}_{2}+\mathrm{NC}$ group and miR-20b inhibitor $+\mathrm{H}_{2} \mathrm{O}_{2}+$ siTXNIP group.

CCK-8 assay. The experimental operation of determining cell viability was performed according to the protocol of the CCK-8 (Beyotime Institute of Biotechnology). The cells were cultured at $37^{\circ} \mathrm{C}$ with $95 \% \mathrm{O}_{2}$ and $5 \% \mathrm{CO}_{2}$ in an incubator for $24 \mathrm{~h}$, and CCK- 8 solution was then added to further culture the cells for $2 \mathrm{~h}$. The optical density (OD) value of each well was measured at $450 \mathrm{~nm}$ by enzyme-labeling instrument (Muliskan MK3; Thermo Fisher Scientific, Inc.).

$S A$ - $\beta$-gal assay. The previously treated HUVECs were washed twice by PBS (Gibco; Thermo Fisher Scientific, Inc.) and fixed by cell fixative solution in $\beta$-gal staining kit (Beyotime Institute of Biotechnology) for $20 \mathrm{~min}$ at $37^{\circ} \mathrm{C}$. Next, the cells were washed three times by PBS to remove the solution. $\beta$-gal dyeing liquid prepared in following the instruction was mixed with the cells and incubated together overnight in a regular incubator at $37^{\circ} \mathrm{C}$ for $24 \mathrm{~h}$ without $\mathrm{CO}_{2}$. The cells with blue cytoplasm by $\beta$-gal staining were positive under a light microscope (BX41; Olympus Corporation). A total of 10 fields in each group were selected under the microscope and the total cells and SA- $\beta$-gal positive cells in each field were counted by ImageJ (version 5.0; Bio-Rad Laboratories, Inc.). The proportion of positive cells was obtained by calculating the ratio of average SA- $\beta$-gal positive cell number to average total cell number in each group.

Cell cycle assay. The cells were fixed by precooled $70 \%$ ethanol at $4^{\circ} \mathrm{C}$ overnight, then re-suspended in PBS and cultured with RNAase $(10 \mathrm{mg} / \mathrm{ml})$ at $4^{\circ} \mathrm{C}$ for $1 \mathrm{~h}$. The cells were then incubated with propidium iodide (PI; $10 \mu \mathrm{g} / \mathrm{ml}$ ) solution in the dark at $4^{\circ} \mathrm{C}$ for $1 \mathrm{~h}$. The FACSCalibur Flow Cytometer (BD Biosciences; Becton, Dickinson and Company) was used to detect cell cycle, and data were processed by CellQuest software (version 5.1; BD Biosciences; Becton, Dickinson and Company).

Target gene prediction of miR-20b. Potential target genes for miR-20b were predicted by Targetscan (http://www.targetscan. org/). RT-qPCR was carried out to determine the effect of miR-20b on the expression of target genes and Targetscan was used to predict the binding sites between the target genes and miR-20b.

Plasmid transfection and dual luciferase reporter assay. The binding ability of miR-20b and target genes was detected by dual luciferase reporter. The wild-type or mutant (mut) 3'-untranslated region (UTR) sequences of TXNIP, or NLRP3 targeting miR-20b was amplified by RT-qPCR and then respectively inserted into the pGL3 control vectors (Promega 
Table I. The sequences required for transfection.

\begin{tabular}{ll}
\hline Sequence & \multicolumn{1}{c}{ 5'-3' $^{\prime}$} \\
\hline miR-20b mimics & ACUGUAGUAUGGGCACUUCCAG \\
miR-20b inhibitor & UGCUCAUAGUGCAGGUAGUU \\
Scramble & CAUACAUUACCCGAAGUCUA \\
siTXNIP & \\
Forward & CUCCCUGCUAUAUGGAUGUTT \\
Reverse & ACAUCCAUAUAGCAGGGAGTT \\
siTXNIP negative & \\
control & \\
Forward & UUCUCCGAACGUGUCACGUTT \\
Reverse & ACGUGACACGUUCGGAGGAGAATT \\
\hline
\end{tabular}

miR, microRNA; si, small interfering.

Corporation). The HUVECs were randomly divided into eight groups, namely: Control + TXNIP-3'-UTR group, miR-20b mimic + TXNIP-3'-UTR group, Control + TXNIP-3'-UTR mut group, miR-20b mimic + TXNIP-3'-UTR mut group, Control + NLRP3-3'-UTRgroup, miR-20b mimic + NLRP3-3'-UTR group, Control + NLRP3-3'-UTR mut group and miR-20b mimic + NLRP3-3'-UTR mut group and transfected by Lipofectamine 2000 Transfection Reagent (Invitrogen; Thermo Fisher Scientific, Inc.). The recombinant vectors or miR-20b mimic was respectively transfected into the cells for $24 \mathrm{~h}$. The luciferase activities were measured using the Dual-Glo Luciferase assay kits (Promega Corporation) and normalized using a Renilla luciferase reference plasmid.

$R T-q P C R$. Total RNA was extracted by using TRIzol reagent (Invitrogen; Thermo Fisher Scientific, Inc.) and total RNA $(2 \mu \mathrm{g})$ were reverse-transcribed into cDNA by using a Taqman MicroRNA Reverse Transcription kit (Applied Biosystems, Inc.) at $37^{\circ} \mathrm{C}$ for $15 \mathrm{~min}$, at $85^{\circ} \mathrm{C}$ for $5 \mathrm{sec}$ and preserved at $4^{\circ} \mathrm{C}$. A SYBR-Green Master (Rox) kit (Thermo Fisher Scientific, Inc.) and RT-qPCR Detection System (ABI 7500; Life Technology; Thermo Fisher Scientific, Inc.) were used to perform RT-qPCR, the cycles were set as follows: Pretreatment at $95^{\circ} \mathrm{C}$ for $2 \mathrm{~min}$, followed by 40 cycles at $95^{\circ} \mathrm{C}$ for $30 \mathrm{sec}$, at $60^{\circ} \mathrm{C}$ for $35 \mathrm{sec}$ and at $95^{\circ} \mathrm{C}$ for $15 \mathrm{sec}$ and finally preserved at $4^{\circ} \mathrm{C}$. The $2^{-\Delta \Delta \mathrm{Cq}}$ method was used to calculate the data (15). U6 and GAPDH expression served as the internal control. The primer sequences for RT-qPCR are shown in Table II.

Western blotting (WB). The cells were lysed to obtain total proteins using radio immunoprecipitation assay lysis buffer (RIPA; Sigma Aldrich; Merck KGaA). The concentration of proteins was determined by Pierce BCA Protein Assay kit (Thermo Fisher Scientific, Inc.) and equal amounts of total proteins $(2 \mu \mathrm{g})$ were added to $10 \%$ SDS-PAGE and transferred to polyvinylidene difluoride membrane (PVDF; Bio-Rad Laboratories, Inc.). The PVDF membrane was blocked by 5\% non-fat milk at room temperature for $30 \mathrm{~min}$ and first incubated with primary antibodies for $4^{\circ} \mathrm{C}$ overnight and then with secondary antibodies for $2 \mathrm{~h}$. The antibodies used during WB were anti-TXNIP antibody (Rabbit; cat. no. ab188865; 1:1,000; Abcam), anti-GAPDH antibody (mouse; cat. no. ab8245; 1:1,000; Abcam), anti-NLRP3 antibody (Rabbit; cat. no. ab214185; 1:200; Abcam), anti-Cleaved Caspase-1 antibody (Rabbit; cat. no. 4199; 1:1,000; Cell Signaling Technology, Inc.), anti-Caspase-1 antibody (Rabbit; cat. no. 3866; 1:1,000; Cell Signaling Technology, Inc.), anti- $\beta$-catenin antibody (Rabbit, cat. no. ab32572; 1:5,000; Abcam), goat anti-mouse IgG H\&L (HRP; 1:2,000; cat. no. ab205719; Abcam) and goat anti-rabbit IgG H\&L (HRP; 1:2,000; cat. no. ab205718; Abcam). ECL Blotting Detection Reagents (Applygen Technologies, Inc.) was used to analyze the protein bands. The gray values of the protein bands were analyzed by ImageJ (version 5.0; Bio-Rad, Laboratories, Inc.) and the relative expressions of the target proteins were determined by the ratio of the gray scale of target protein to the internal reference. GAPDH served as internal control.

Statistical analysis. Data were analyzed by SPSS 21.0 system (IBM, Corps.) and shown as the mean \pm standard deviation. Significant differences among different groups were analyzed using analysis of variance followed by the Tukey post hoc test. $\mathrm{P}<0.05$ was considered to indicate a statistically significant difference. All experiments were repeated three times.

\section{Results}

$\mathrm{H}_{2} \mathrm{O}_{2}$ induces cell senescence and inhibits miR-20b expression. The cell viability, senescence and cycle of the HUVECs were determined by CCK- 8 , SA- $\beta$-gal staining and flow cytometry, respectively, after treating HUVECs at different $\mathrm{H}_{2} \mathrm{O}_{2}$ concentrations $(0,10,50,100$ and $500 \mu \mathrm{M})$. It was found that $\mathrm{H}_{2} \mathrm{O}_{2}$ at 50,100 or $500 \mu \mathrm{M}$ significantly reduced the cell viability of HUVECs compared with $0 \mu \mathrm{M}(\mathrm{P}<0.01$; Fig. 1A). As shown in Fig. 1B, the blue cytoplasm was positive and the proportion of the positive cells significantly increased as the concentration of $\mathrm{H}_{2} \mathrm{O}_{2}$ became higher ( $\mathrm{P}<0.01$; Fig. 1B). At the same time, the proportion of HUVECs in G1 phase significantly increased with the increase of $\mathrm{H}_{2} \mathrm{O}_{2}$ concentration, while the proportion of HUVECs in $\mathrm{S}$ and $\mathrm{G} 2$ phase significantly decreased after $\mathrm{H}_{2} \mathrm{O}_{2}$ treatment $(\mathrm{P}<0.01$; Fig. 1C). The results suggested that $\mathrm{H}_{2} \mathrm{O}_{2}$ inhibited cell viability, caused cell cycle arrest in G1 phase and induced cell senescence.

Moreover, the expression level of miR-20b in HUVECs was determined by RT-qPCR and the present study found that the miR-20b level was significantly downregulated by $\mathrm{H}_{2} \mathrm{O}_{2}$ treatment $(\mathrm{P}<0.01$; Fig. 1D). The percentage of SA- $\beta$-gal+ cells in HUVECs exposed to $\mathrm{H}_{2} \mathrm{O}_{2}$ at $50 \mu \mathrm{M}$ was only $\sim 4 \%$, while the percentage of SA- $\beta$-gal + cells in HUVECs exposed to $\mathrm{H}_{2} \mathrm{O}_{2}$ at $100 \mu \mathrm{M}$ was $7 \%$ (Fig. 1B). Based on the above results and previous studies $(16,17)$, to obtain more senescent cells and avoid potentially excessive damage from $\mathrm{H}_{2} \mathrm{O}_{2}$ at higher concentration $(500 \mu \mathrm{M}), \mathrm{H}_{2} \mathrm{O}_{2}$ at $100 \mu \mathrm{M}$ was chosen for further experiments.

HUVECs cells are successfully transfected with an miR-20b mimic or miR-20b inhibitor. In order to investigate the effect of miR-20b expression on the senescence of HUVECs, the miR-20b mimic and miR-20b inhibitor were respectively transfected into cells. RT-qPCR was performed to confirm 
Table II. The primer sequences for reverse transcription-quantitative PCR.

\begin{tabular}{lll}
\hline Primer & \multicolumn{1}{c}{ Forward sequence (5'-3') } & \multicolumn{1}{c}{ Reverse sequence (5'-3') } \\
\hline miR-20b & GCTCATAGTGCAGGTAGAA & TGTCAACGATACGCTACG \\
STAT3 & CCTTCCTCACCGTGTACTGG & AGCGTAGGGTAAGGTTCTTGC \\
SMAD7 & ACTCCAGATACCCGATGGATTT & CCTCCCAGTATGCCACCAC \\
TXNIP & CAGAAGCTCCTCCCTGCTATATG & GATGCAGGGATCCACCTCAG \\
NLRP3 & CTTCCTTTCCAGTTTGCTGC & TCTCGCAGTCCACTTCCTTT \\
p16 & CACGGGTCGGGTGAGAGT & CCCAACGCACCGAATAGTTAC \\
p21 & GCCTGGACTGTTTTCTCTCG & ATTCAGCATTGTGGGAGGAG \\
U6 & CTCGCTTCGGCAGCACA & AACGCTTCACGAATTTCGT \\
GAPDH & AGTCAGCTCTCTCCTTTCAGG & TCCACCACCCTGTTGCTGTA
\end{tabular}

miR, microRNA; STAT3, signal transducer and activator of transcription 3; SMAD7, mothers against decapentaplegic homolog 7; TXNIP, thioredoxin interacting protein; NLRP3, NLR family pyrin domain containing 3.
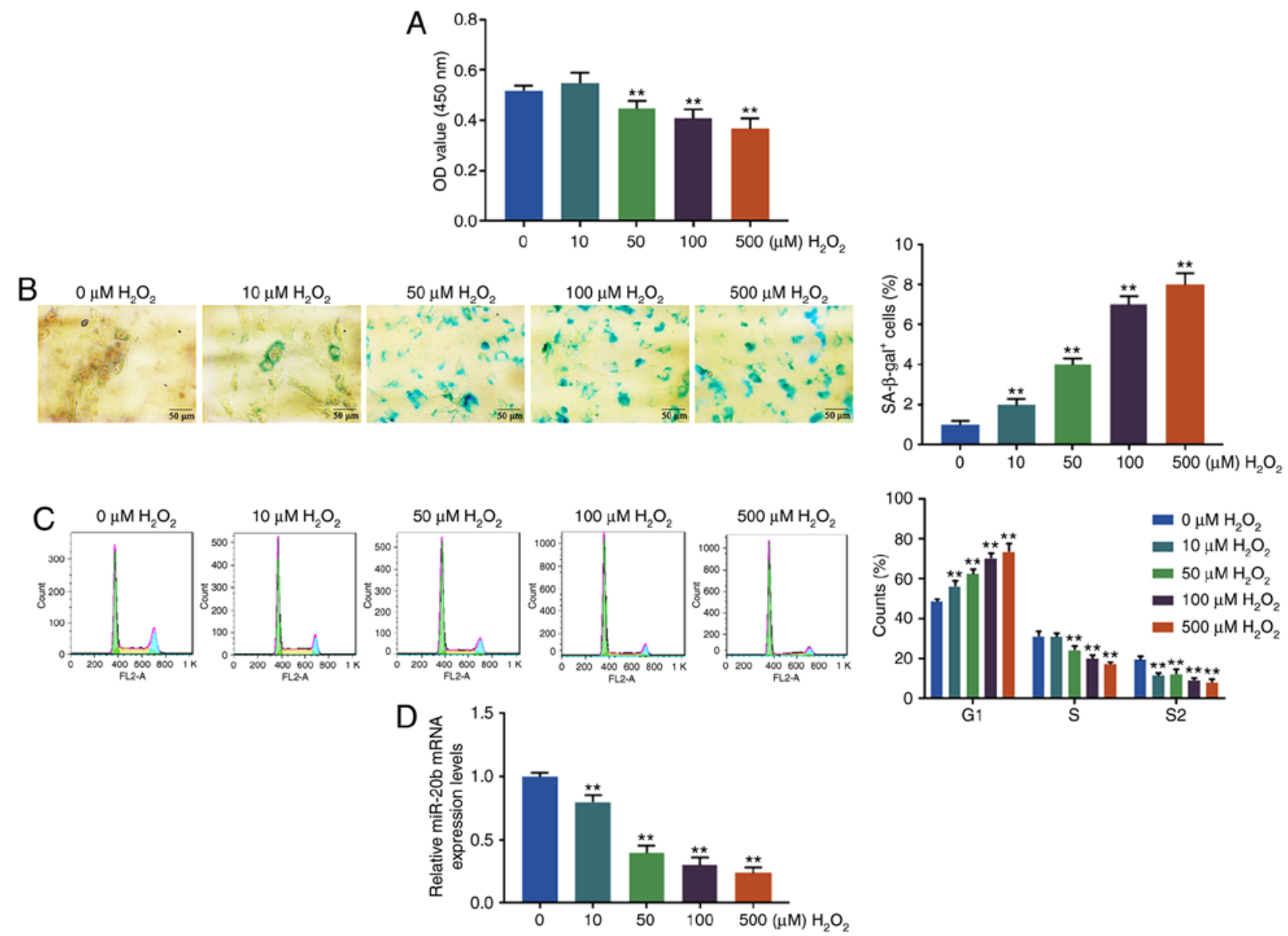

Figure 1. Cell senescence induced by oxidative stress. (A) Cell viability was determined by Cell Counting Kit- 8 . (B) Cell senescence was detected by SA- $\beta$-gal staining. (C) The cell cycle was determined by flow cytometry. (D) The miR-20b level was detected by reverse transcription quantitative-PCR. The human umbilical vein endothelial cells were randomly divided into 5 groups and treated with different concentrations of $\mathrm{H}_{2} \mathrm{O}_{2}(0,10,50,100$ and $500 \mu \mathrm{M})$. The blank group $\left(0 \mu \mathrm{M} \mathrm{H}_{2} \mathrm{O}_{2}\right)$ was cultured in normal medium. The $\mathrm{H}_{2} \mathrm{O}_{2}$ group was incubated by normal medium with different concentrations of $\mathrm{H}_{2} \mathrm{O}_{2}$. The experiments were repeated in triplicate. ${ }^{* *} \mathrm{P}<0.001$ vs. $0 \mu \mathrm{M} \mathrm{H}_{2} \mathrm{O}_{2}$. miR, microRNA; OD, optical density; SA- $\beta$-gal, SA- $\beta$-galactosidase.

whether the transfection was successfully conducted. The results demonstrated that compared with the scramble group, the expression of the miR-20b in miR-20b mimic and miR-20b mimic $+\mathrm{H}_{2} \mathrm{O}_{2}$ group were increased, while those in miR-20b inhibitor, scramble $+\mathrm{H}_{2} \mathrm{O}_{2}$ and miR-20b inhibitor $+\mathrm{H}_{2} \mathrm{O}_{2}$ group were significantly decreased $(\mathrm{P}<0.05$; Fig. 2A). Compared with the scramble $+\mathrm{H}_{2} \mathrm{O}_{2}$ group, the miR-20b expression was significantly increased in miR-20b mimic $+\mathrm{H}_{2} \mathrm{O}_{2}$ group, but significantly decreased in miR-20b inhibitor $+\mathrm{H}_{2} \mathrm{O}_{2}$ group $(\mathrm{P}<0.05$; Fig. 2A). Therefore, the present results showed that 


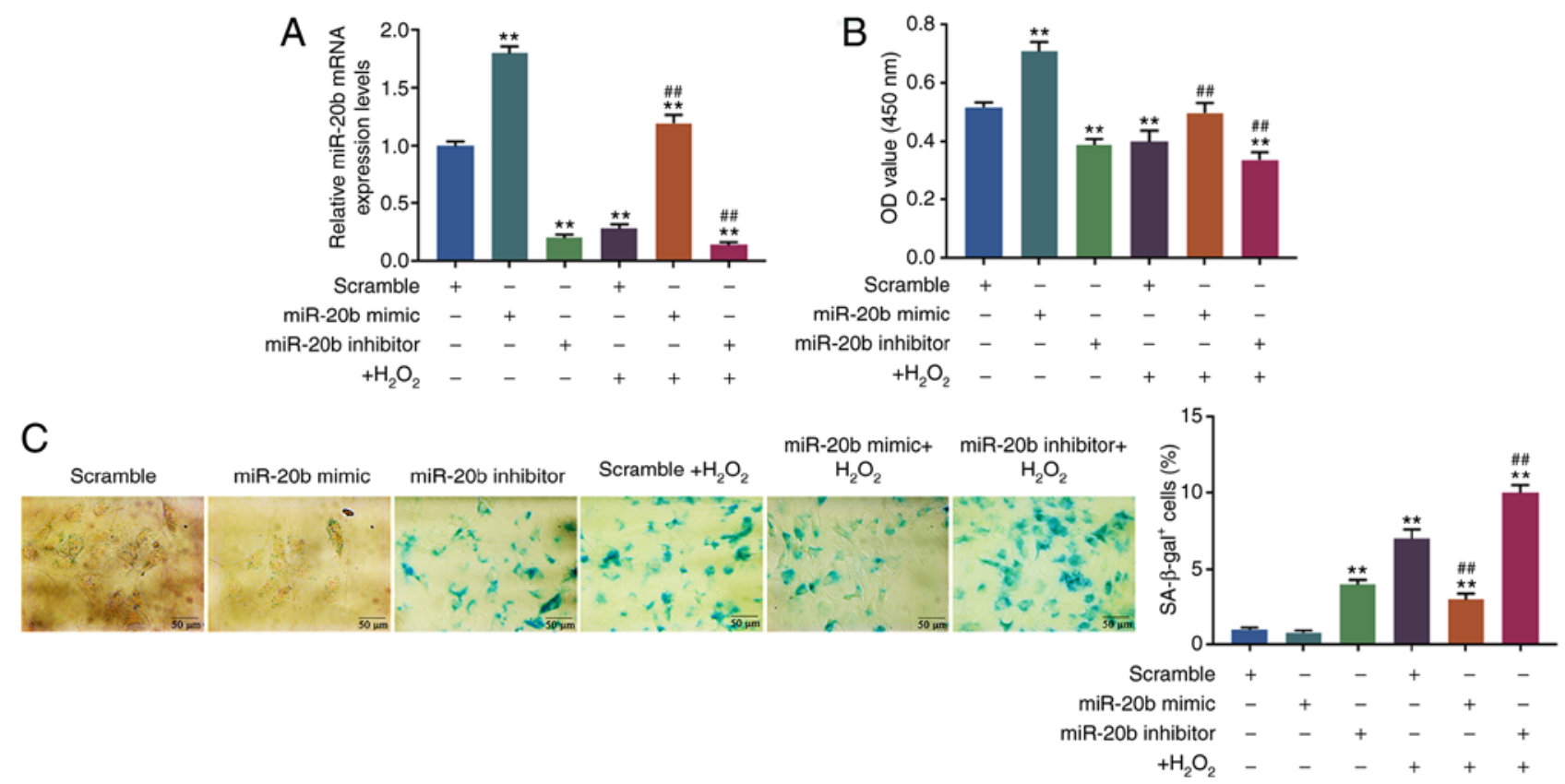

Figure 2. Effects of miR-20b expression level on cell senescence. (A) The cells were transfected with the miR-20b mimic, miR-20b inhibitor or scramble and the transfection rate was detected by reverse transcription-quantitative PCR. (B) The effect of miR-20b on cell viability was detected by Cell Counting Kit-8. (C) The effect of miR-20b on cell senescence was detected by SA- $\beta$-gal staining. The HUVECs were divided into 6 groups, namely the scramble group, miR-20b mimic group, miR-20b inhibitor group, scramble $+\mathrm{H}_{2} \mathrm{O}_{2}$ group, miR-20b mimic $+\mathrm{H}_{2} \mathrm{O}_{2}$ group and miR-20b inhibitor $+\mathrm{H}_{2} \mathrm{O}_{2}$ group. The cells were transfected with the miR-20b mimic, miR-20b inhibitor or scramble and then stimulated with $\mathrm{H}_{2} \mathrm{O}_{2}(100 \mu \mathrm{M})$, or left untreated. ${ }^{* *} \mathrm{P}$ vs. scramble; ${ }^{\# \#} \mathrm{P}<0.001$ vs. scramble $+\mathrm{H}_{2} \mathrm{O}_{2}$. HUVECs, human umbilical vein endothelial cells; miR, microRNA; SA- $\beta$-gal, SA- $\beta$-galactosidase; OD, optical density.

the expression of miR-20b in HUVECs was successfully upregulated and downregulated.

High expression of miR-20b inhibits cell senescence. The cell viability and senescence were determined by CCK- 8 and SA- $\beta$-gal staining, respectively, and it was found that the cell viability was upregulated in miR-20b mimic group but downregulated in miR-20b inhibitor and miR-20b inhibitor $+\mathrm{H}_{2} \mathrm{O}_{2}$ group compared with the scramble group $(\mathrm{P}<0.05$; Fig. 2B). In comparison with the scramble $+\mathrm{H}_{2} \mathrm{O}_{2}$ group, the cell viability was increased in the miR-20b mimic $+\mathrm{H}_{2} \mathrm{O}_{2}$ group but decreased in the miR-20b inhibitor $+\mathrm{H}_{2} \mathrm{O}_{2}$ group $(\mathrm{P}<0.05$; Fig. 2B).

Moreover, the SA- $\beta$-gal staining results showed that the proportion of $\beta$-gal positive cells significantly increased in the miR-20b inhibitor, scramble $+\mathrm{H}_{2} \mathrm{O}_{2}$, miR-20b mimic + $\mathrm{H}_{2} \mathrm{O}_{2}$ and miR-20b inhibitor $+\mathrm{H}_{2} \mathrm{O}_{2}$ group $(\mathrm{P}<0.05$; Fig. 2C). However, compared with scramble $+\mathrm{H}_{2} \mathrm{O}_{2}$ group, the proportion of $\beta$-gal positive cells decreased in the miR-20b mimic + $\mathrm{H}_{2} \mathrm{O}_{2}$ group but increased in miR-20b inhibitor $+\mathrm{H}_{2} \mathrm{O}_{2}$ group ( $\mathrm{P}<0.05$; Fig. 2C).

The results indicated that miR-20b could increase cell viability and inhibit cell senescence, and that miR-20b produced protective effect on HUVECs cells from $\mathrm{H}_{2} \mathrm{O}_{2}$-induced cell senescence.

TXNIP is the target gene for miR-20b. Targetscan predicted that the possible target genes for miR-20b were signal transducer and activator of transcription 3 (STAT3), mothers against decapentaplegic homolog 7 (SMAD7), TXNIP and NLRP3. RT-qPCR was performed to detect the effect of miR-20b on the possible target genes and it was found that in the scramble
$+\mathrm{H}_{2} \mathrm{O}_{2}$, miR-20b mimic $+\mathrm{H}_{2} \mathrm{O}_{2}$, and miR-20b inhibitor $+\mathrm{H}_{2} \mathrm{O}_{2}$ groups, the levels of STAT3 were significantly downregulated, while that of SMAD7 was significantly upregulated compared with the scramble group ( $\mathrm{P}<0.05$; Fig. 3A). The levels of TXNIP and NLRP3 were significantly decreased in the miR-20b mimic group compared with those in the scramble group, but were still increased in the miR-20b inhibitor, scramble + $\mathrm{H}_{2} \mathrm{O}_{2}$, miR-20b mimic $+\mathrm{H}_{2} \mathrm{O}_{2}$ and miR-20b inhibitor $+\mathrm{H}_{2} \mathrm{O}_{2}$ groups compared with those in the scramble group $(\mathrm{P}<0.05$; Fig. 3A). Compared with the scramble $+\mathrm{H}_{2} \mathrm{O}_{2}$ group, the levels of TXNIP and NLRP3 were significantly downregulated in the miR-20b mimic $+\mathrm{H}_{2} \mathrm{O}_{2}$ group but were significantly upregulated in the miR-20b inhibitor $+\mathrm{H}_{2} \mathrm{O}_{2}$ group $(\mathrm{P}<0.05$; Fig. 3A). Thus, the data indicated that the TXNIP and NLRP3 may be the target genes for miR-20b.

In order to further determine the direct target gene for miR-20b, Targetscan website was used to predict the binding sites between miR-20b and TXNIP, and NLRP3 (Fig. 3B), and the results were further verified by dual luciferase reporter assay. The present study observed that in the miR-20b mimic + TXNIP-3'-UTR and miR-20b mimic + NLRP3-3'-UTR groups, the relative luciferase activities were significantly decreased, and the relative luciferase activity changes of TXNIP was the most significant $(\mathrm{P}<0.05$; Fig. $3 \mathrm{C}$ and $\mathrm{D})$. Thus, TXNIP was determined as the direct target gene for miR-20b.

siTXNIP reverses the effects of miR-2Ob inhibitor and $\mathrm{H}_{2} \mathrm{O}_{2}$. In order to investigate the mechanism of miR-20b in the cell senescence of HUVECs, TXNIP siRNA was used to transform HUVECs and the results were verified by RT-qPCR and WB. As shown in Fig. 4B and C, the expression of TXNIP decreased significantly in siTXNIP group $(\mathrm{P}<0.05)$, suggesting 


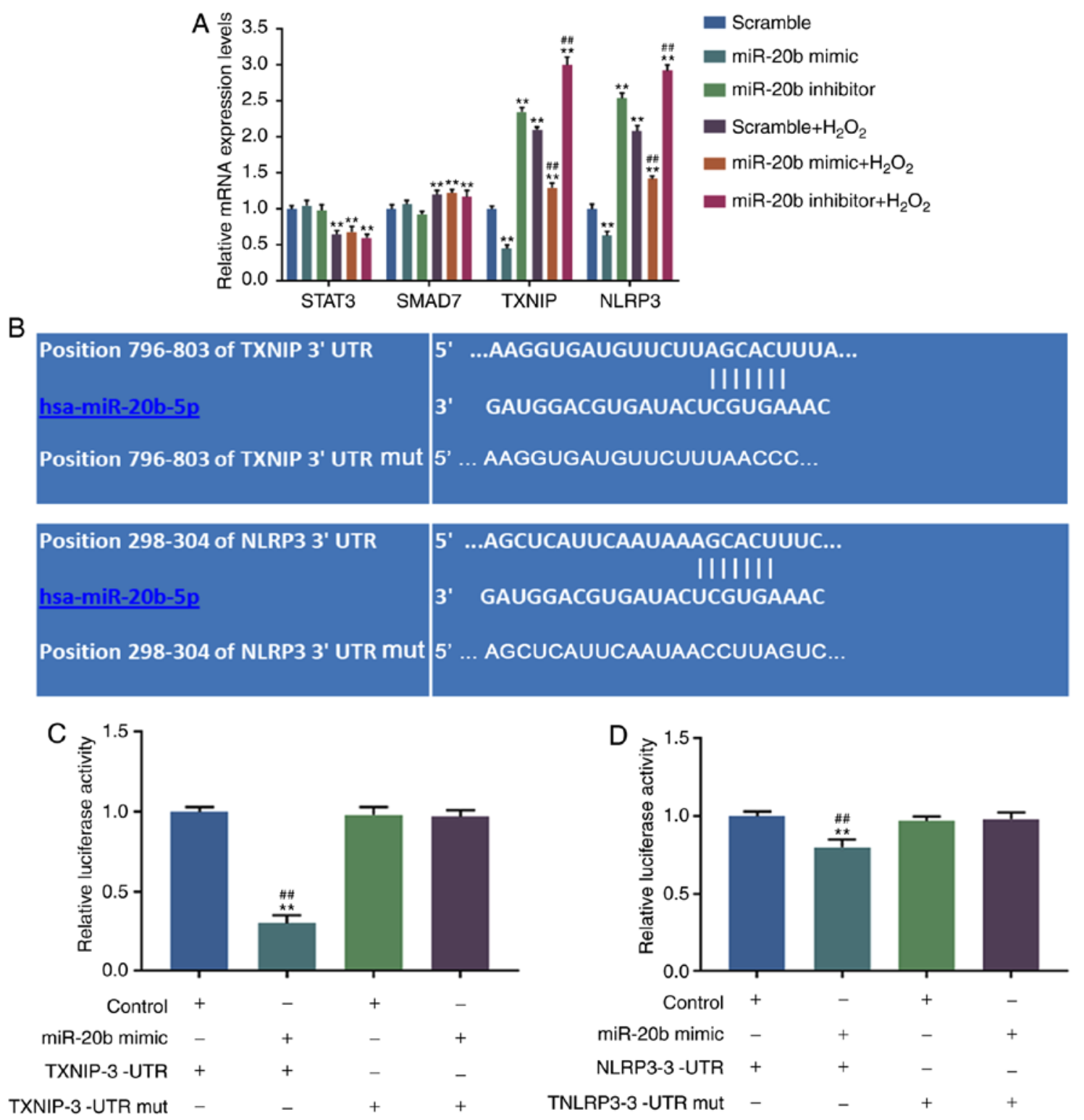

Figure 3. Target gene of miR-20b was predicted. (A) The potential target genes of miR-20b were predicted by Targetscan (http://www.targetscan.org/) and RT-qPCR was performed for detection. ${ }^{* *} \mathrm{P}<0.001$ vs. scramble; ${ }^{\# \#} \mathrm{P}<0.001$ vs. scramble $+\mathrm{H}_{2} \mathrm{O}_{2}$. (B) The binding sites of the target gene and miR-20b were predicted by Targetscan. (C) The binding abilities of miR-20b and TXNIP were detected by dual luciferase reporter. ${ }^{* *} \mathrm{P}<0.001$ vs. Control + TXNIP-3'-UTR; ${ }^{\# \#} \mathrm{P}<0.001$ vs. miR-20b mimic + TXNIP-3'-UTR mut. (D) The binding abilities of miR-20b and NLRP3 were detected by dual luciferase reporter. ${ }^{* *} \mathrm{P}<0.001 \mathrm{vs}$. Control + TXNIP-3'-UTR; ${ }^{\# \prime}$ P $<0.001$ vs. miR-20b mimic + TXNIP-3'-UTR mut. HUVECs were divided into 8 groups, namely, Control + TXNIP-3'-UTR group, miR-20b mimic + TXNIP-3'-UTR group, Control + TXNIP-3'-UTR mut group, miR-20b mimic + TXNIP-3'-UTR mut group, Control + NLRP3-3'-UTRgroup, miR-20b mimic + NLRP3-3'-UTR group, Control + NLRP3-3'-UTR mut group and miR-20b mimic + NLRP3-3'-UTR mut group. The pGL3 control vectors were used to generate recombinant vectors with mut sequence or a 3'UTR sequence of TXNIP or NLRP3 and the recombinant vectors and/or miR-20b mimic were transfected into cells. Mut, mutant; UTR, untranslated region; NLRP3, NLR family pyrin domain containing 3; HUVECs, human umbilical vascular cell; TXNIP, thioredoxin interacting protein.

that HUVECs cells with a low expression of TXNIP were successfully constructed.

The cell viability and senescence of HUVECs were determined by CCK- 8 and SA- $\beta$-gal staining, respectively, and it was found that the cell viability of HUVECs was increased in the siTXNIP group compared with in the NC group, moreover, the miR-20b inhibitor + NC group had a lower cell viability compared with in the miR-20b inhibitor + siTXNIP group. Furthermore, the cell viability of HUVECs was significantly increased in the miR-20b inhibitor $+\mathrm{H}_{2} \mathrm{O}_{2}+$ siTXNIP group compared with in miR-20b inhibitor $+\mathrm{H}_{2} \mathrm{O}_{2}+\mathrm{NC}$ group $(\mathrm{P}<0.05$; Fig. 4D) and the cell viability in miR-20b inhibitor
$+\mathrm{NC}$ and miR-20b inhibitor $+\mathrm{H}_{2} \mathrm{O}_{2}+\mathrm{NC}$ groups decreased compared with $\mathrm{NC}$ group $(\mathrm{P}<0.05$; Fig. 4D).

SA- $\beta$-gal staining results showed that the proportions of $\beta$-gal positive cells in miR-20b inhibitor $+\mathrm{NC}$ and miR-20b inhibitor $+\mathrm{H}_{2} \mathrm{O}_{2}+\mathrm{NC}$ groups were significantlu increased compared with the $\mathrm{NC}$ group $(\mathrm{P}<0.05$; Fig. $4 \mathrm{E})$, but decreased in the miR-20b inhibitor + siTXNIP group compared with in miR-20b inhibitor $+\mathrm{NC}$ group $(\mathrm{P}<0.05$; Fig. 4E). Moreover, the number of $\beta$-gal positive cells was significantly increased in miR-20b inhibitor $+\mathrm{H}_{2} \mathrm{O}_{2}+$ siTXNIP group compared with that in miR-20b inhibitor + $\mathrm{H}_{2} \mathrm{O}_{2}+\mathrm{NC}$ group $(\mathrm{P}<0.05$; Fig. 4E). 

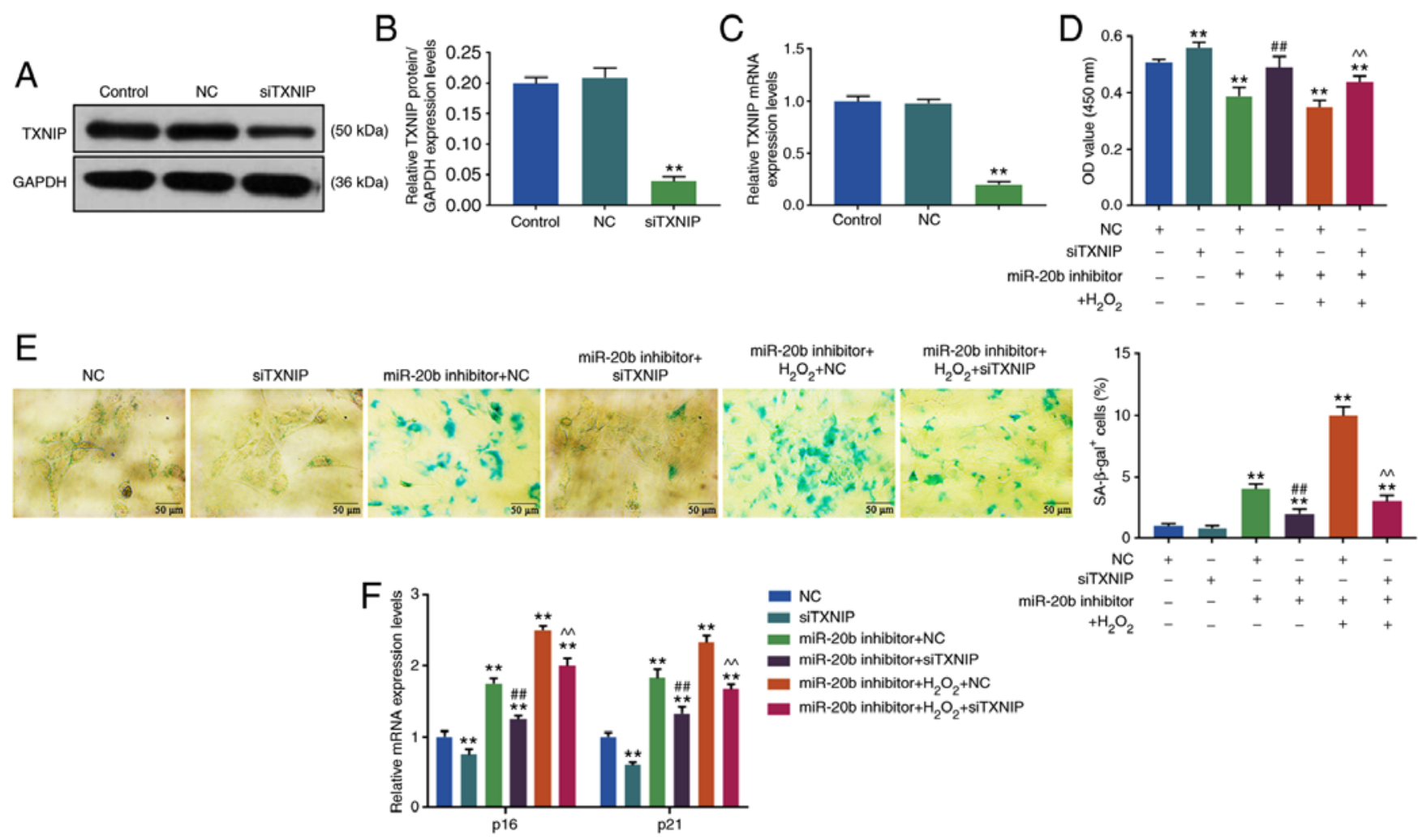

Figure 4. Effects of siTXNIP on cell senescence. (A) Western blotting was used to determine the level of TXNIP. The knockdown of TXNIP was achieved by siRNA, the HUVECs cells were transfected with siTXNIP, the blank control group and NC group were set at the same time (Control group, NC group, and siTXNIP group). (B) The siTXNIP reduced the expression of TXNIP protein. (C) RT-qPCR was used to determine the TXNIP mRNA expression. (D) Cell viability was detected by Cell Counting Kit-8. The HUVECs were divided into 6 groups, namely, NC group, siTXNIP group, miR-20b inhibitor + NC group, miR-20b inhibitor + siTXNIP group, miR-20b inhibitor $+\mathrm{H}_{2} \mathrm{O}_{2}+\mathrm{NC}$ group and miR-20b inhibitor $+\mathrm{H}_{2} \mathrm{O}_{2}+$ siTXNIP group. The cells were co-transfected with miR-20b inhibitor and siTXNIP or NC, and stimulated by $\mathrm{H}_{2} \mathrm{O}_{2}(100 \mu \mathrm{M})$, or left untreated. (E) Cell senescence was detected by SA- $\beta$-gal staining. (F) The expression of cell senescence-related genes were detected by RT-qPCR. ${ }^{* *} \mathrm{P}<0.001$ vs. NC; ${ }^{\# \#} \mathrm{P}<0.001$ vs. miR-20b inhibitor $+\mathrm{NC}$; ${ }^{\wedge} \mathrm{P}<0.001$ vs. miR-20b inhibitor $+\mathrm{H}_{2} \mathrm{O}_{2}+$ NC. RT-qPCR, reverse transcription-quantitative; miR, microRNA; si, small interfering; HHUVECs, human umbilical vascular endothelial cells; NC, negative control; TXNIP, thioredoxin interacting protein.

The present data suggested that siTXNIP increased cell viability and partially reversed the inhibitory effects of miR-20b inhibitor and $\mathrm{H}_{2} \mathrm{O}_{2}$ on cell viability and the promoting effects of miR-20b inhibitor and $\mathrm{H}_{2} \mathrm{O}_{2}$ on cell senescence.

SiTXNIP reduces the expression of cell senescence-related genes. The results of WB showed that compared with NC group, the levels of p16 and p21 were decreased in siTXNIP group but were significantly increased in the miR-20b inhibitor $+\mathrm{NC}$ and miR-20b inhibitor $+\mathrm{H}_{2} \mathrm{O}_{2}+\mathrm{NC}$ groups $(\mathrm{P}<0.05$; Fig. 4F). However, the levels of p16 and p21 were decreased in the miR-20b inhibitor + siTXNIP group compared with those in the miR-20b inhibitor + NC group, and that the levels of p16 and p21 were lower in the miR-20b inhibitor $+\mathrm{H}_{2} \mathrm{O}_{2}+$ siTXNIP group compared with those in miR-20b inhibitor $+\mathrm{H}_{2} \mathrm{O}_{2}+\mathrm{NC}$ group $(\mathrm{P}<0.05$; Fig. 4F).

Compared with NC group, the expression of TXNIP, NLRP3 and cleaved Caspase-1 was significantly decreased in the siTXNIP group but increased in the miR-20b inhibitor $+\mathrm{NC}$ and miR-20b inhibitor $+\mathrm{H}_{2} \mathrm{O}_{2}+\mathrm{NC}$ groups $(\mathrm{P}<0.05$; Fig. 5B). Moreover, compared with the miR-20b inhibitor $+\mathrm{NC}$ group, the expression of TXNIP, NLRP3 and cleaved Caspase-1 in miR-20b inhibitor + siTXNIP group was decreased. However, the present study also found that the expression of TXNIP, NLRP3 and cleaved Caspase-1 was significantly decreased lower in the miR-20b inhibitor $+\mathrm{H}_{2} \mathrm{O}_{2}+$ siTXNIP group compared with miR-20b inhibitor $+\mathrm{H}_{2} \mathrm{O}_{2}+\mathrm{NC}$ group, $(\mathrm{P}<0.05$; Fig. 5B). Thus, the data showed that siTXNIP reduced the expression of senescence-related genes and inhibited cell senescence.

SiTXNIP inhibits the Wnt/ $\beta$-catenin signaling pathway. The present study found that compared with NC group, the expression level of $\beta$-catenin was downregulated in siTXNIP group but was significantly upregulated in miR-20b inhibitor $+\mathrm{H}_{2} \mathrm{O}_{2}+\mathrm{NC}$ group $(\mathrm{P}<0.05$; Fig. 5D), at the same time, the expression of $\beta$-catenin in miR-20b inhibitor + siTXNIP and miR-20b inhibitor $+\mathrm{H}_{2} \mathrm{O}_{2}+$ siTXNIP groups was significantly decreased compared with in the miR-20b inhibitor $+\mathrm{NC}$ and miR-20b inhibitor $+\mathrm{H}_{2} \mathrm{O}_{2}+\mathrm{NC}$ groups $(\mathrm{P}<0.05$; Fig. 5D), suggesting that siTXNIP decreased $\beta$-catenin expression and inhibited the Wnt/ $\beta$-catenin pathway. The working model of miR-20b is shown in Fig. 6.

\section{Discussion}

Organismal aging, which refers to the progressive decline of physiological functions, also involves a series of inevitable physiological events (18-21). Manifested as growth stagnation and changes in gene expression profiles, cell senescence is 

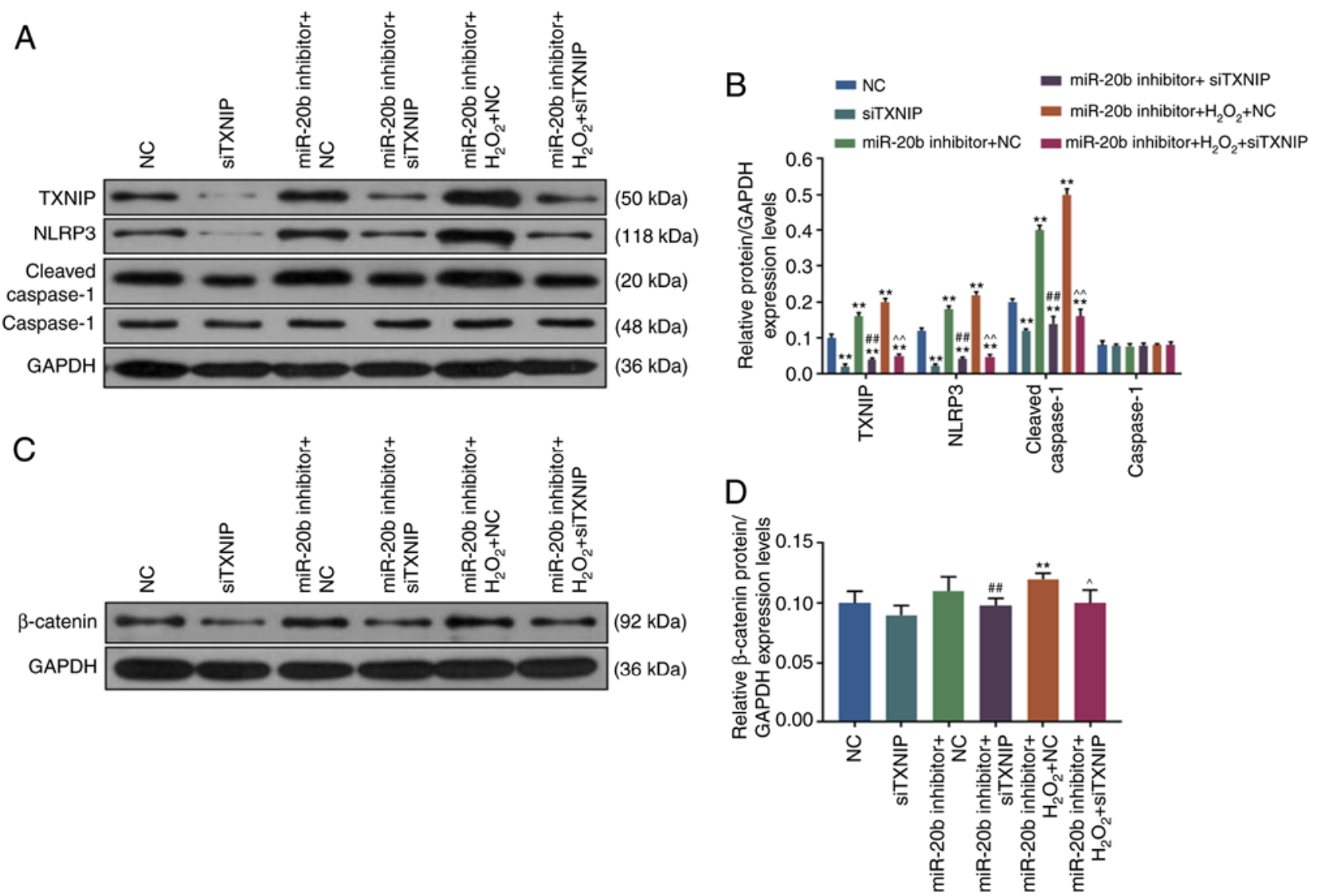

Figure 5. siTXNIP inhibits the Wnt/ $\beta$-catenin pathway. (A) The expression of TXNIP, NLRP3, cleaved Caspase-1 and Caspase-1 was determined by WB. (B) siTXNIP reduced TXNIP, NLRP3 and cleaved Caspase-1 expression. (C) $\beta$-catenin expression was determined by WB. (D) siTXNIP reduced $\beta$-catenin expression. ${ }^{* *} \mathrm{P}<0.001$ vs. $\mathrm{NC} ;{ }^{\# \#} \mathrm{P}<0.001$ vs. miR-20b inhibitor $+\mathrm{NC} ;{ }^{\wedge} \mathrm{P}<0.001$ and ${ }^{\wedge} \mathrm{P}<0.001$ vs. miR-20b inhibitor $+\mathrm{H}_{2} \mathrm{O}_{2}+\mathrm{NC}$. NC, negative control; miR, microRNA; si, small interfering; WB, western blotting; NLRP3, NLR family pyrin domain containing 3; TXNIP, thioredoxin interacting protein.

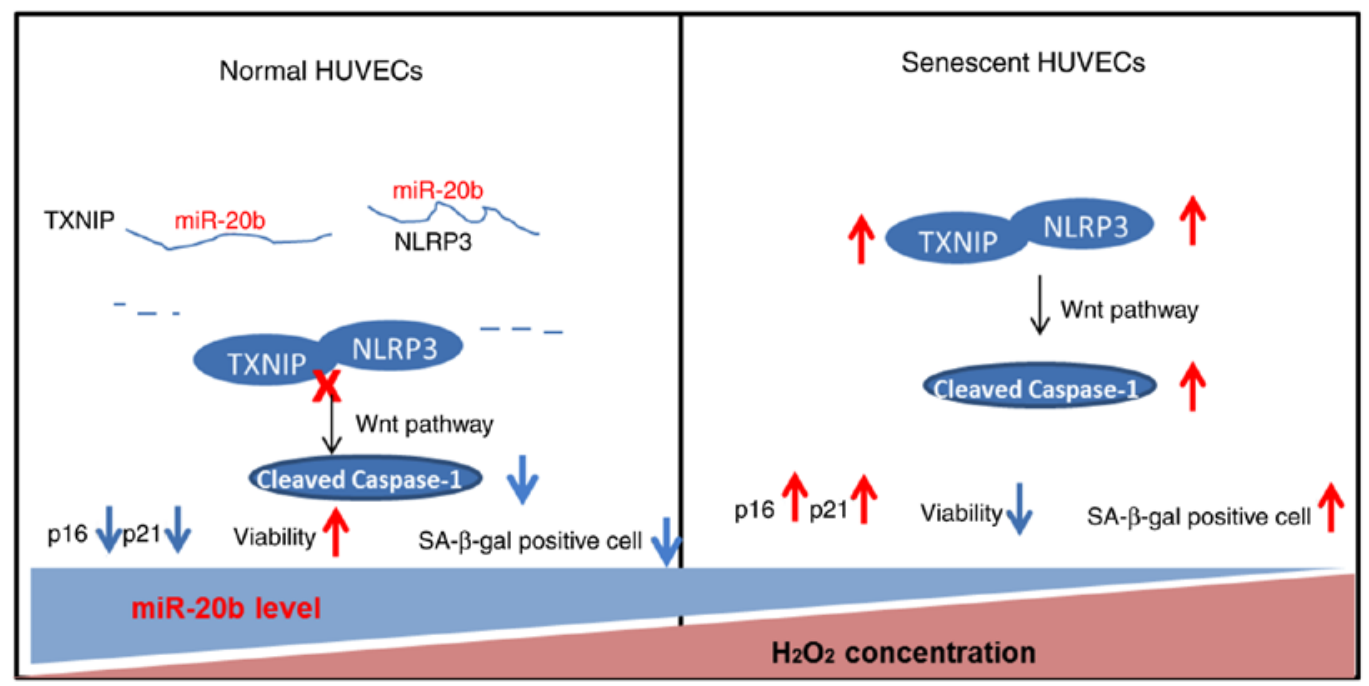

Figure 6. Working model of miR-20b in senescence of HUVECs. $\mathrm{H}_{2} \mathrm{O}_{2}$ induced senescence in HUVECs. The expression level of miR-20b was decreased with the increased concentration of $\mathrm{H}_{2} \mathrm{O}_{2}$. In normal HUVECs without $\mathrm{H}_{2} \mathrm{O}_{2}$ stimulation, miR-20b targeted and suppressed TXNIP and NLRP3 mRNAs, causing decreased cleaved Caspase-1. In senescent HUVECs with $\mathrm{H}_{2} \mathrm{O}_{2}$ stimulation, the absence of miR-20b induced upregulation of TXNIP and NLRP3, causing increased cleaved Caspase-1. HUVECs, human umbilical vascular endothelial cells; miR, microRNA; TXNIP, thioredoxin interacting protein; NLRP3, NLR family pyrin domain containing 3 ; SA- $\beta$-gal, SA- $\beta$-galactosidase.

defined by the irreversible detachment of cells from the cell cycle and the loss of proliferative capacity $(22,23)$. Vascular senescence refers to cellular senescence in the vascular system and is closely related to the occurrence of cardiovascular and metabolic disorders (24). Endothelial cell senescence, which can lead to vascular endothelial dysfunction and aging 
of tissues and organs, is the major risk factor for developing cardiovascular disease (6). A previous study demonstrated that aging of endothelial cells is triggered by a variety of factors such as oxidative stress, ionizing radiation and telomere dysfunction (25). Oxidative stress plays a crucial role in the occurrence of endothelial dysfunction and is characterized by increased oxygen free radical level and damage to organs and tissues $(26,27)$.

A series of structural and functional changes, for example, reduced cell division and proliferation, increased dyeing rate of SA- $\beta$-gal, expression of senescence markers and senescent-associated secretory phenotypes could also occur during the process of endothelial cell senescence (28). It has been reported that different concentrations of $\mathrm{H}_{2} \mathrm{O}_{2}$ treatment can induce cell senescence in a variety of types of cells (29). In the current study, the HUVECs were stimulated by $\mathrm{H}_{2} \mathrm{O}_{2}$ at different concentrations and it was found that the cell viability was decreased, while SA- $\beta$-gal positive cells were increased, and cell cycle arrest occurred after $\mathrm{H}_{2} \mathrm{O}_{2}$ stimulation intervention. Such results indicated that HUVECs cells treated by $\mathrm{H}_{2} \mathrm{O}_{2}$ had typical characteristics of cell senescence and that $\mathrm{H}_{2} \mathrm{O}_{2}$ can induce cell senescence through oxidative stress. Meanwhile, the $\mathrm{H}_{2} \mathrm{O}_{2}$ reduced miR-20b expression. Interestingly, $\mathrm{H}_{2} \mathrm{O}_{2}$ at $10 \mathrm{M}$ did not decrease the cell viability, however, the level of miR-20b was downregulated, suggesting that the miR-20b expression change was more sensitive to $\mathrm{H}_{2} \mathrm{O}_{2}$ stimulation than cell viability change and that the reduced expression in miR-20b at $10 \mathrm{M} \mathrm{H}_{2} \mathrm{O}_{2}$ stimulation was not enough to cause decreased cell viability.

miRNAs are directly involved in the pathological process of numerous cardiovascular diseases (30). Lou et al (31) pointed out the unique role of miR-20b in controlling tuberculosis progression. Wong et al (32) showed that hsa-miR-20b is downregulated in tumor necrosis factor (TNF)- $\alpha$-induced senescent microvascular endothelial cells. In addition, miR-20b is associated with aging and tends to be highly-expressed in the thymus of young mice (33) and upregulated in UVB-induced senescent diploid fibroblasts (34). However, the exact mechanisms of miR-20b in the regulation of endothelial cell senescence remains to be further studied, for such a purpose, the present study successfully constructed HUVECs cells with high and low expression of miR-20b. The results showed that the high expression of miR-20b increased cell viability and inhibited cell senescence, while the low expression of miR-20b produced the opposite effects, suggesting that a high level of miR-20b protected endothelial cells and inhibited $\mathrm{H}_{2} \mathrm{O}_{2}$-mediated cell senescence. These results indicated that loss of miR-20b expression might be involved in promoting senescence of HUVECs. Additionally, it would be better to perform cell cycle analysis on the miR-20b mimic or miR-20b inhibitor transfected cells. However, the present study focused on the cell senescence phenotype and cell viability, and didn't have enough resources to perform the cell cycle assay in each stage of this experiment. In addition, previous studies in animal models indicate that miR-20b is positively involved in hepatic ischaemia/reperfusion injury (35), breast cancer resistance (36), cardiac hypertrophy (37). However, whether it regulates the cardiovascular senescence in animal model remains unknown.
To study the mechanism of miR-20b in endothelial cell senescence, the potential target genes for miR-20b were predicted by Targetscan and verified by RT-qPCR and dual luciferase reporter. One recent report indicated that SMAD7 is a targeted gene for miR-20b in insulin-resistant skeletal muscle (13). Another recent study also showed that miR-20b is a circulating biomarker associated with type 2 diabetes and can target STAT3 (38). In the current study, SMAD7, STAT3, TXNIP and NLRP3 were all predicted to be the targets for miR-20b by Targetscan. However, RT-qPCR and dual luciferase reporter analyses showed that TXNIP and NLRP3 were the main direct target genes for miR-20b, while SMAD7, STAT3 could not be regulated by miR-20b. Nevertheless, the expression of SMAD7 and STAT3 were reduced by $\mathrm{H}_{2} \mathrm{O}_{2}$ stimulation. One study showed that depletion of SMAD7 causes $\beta$ cell aging (39). Another study also indicated that the activation of STAT3 is necessary for TNF $\alpha$-induced senescence (40). Thus, the present study inferred that SMAD7 and STAT3 may have a role in $\mathrm{H}_{2} \mathrm{O}_{2}$-induced cell senescence, although it has not been confirmed in this study. Additionally, it seems that the luciferase activity of cells transfected with TXNIP-3-UTR could be more severely suppressed by the miR-20b mimic than cells transfected with NLRP3-3-UTR, thus TXNIP was chosen for further exploration. siRNA technology was applied to reduce the expression of TXNIP and detect the role of TXNIP in endothelial cell senescence. It was discovered that siTXNIP increased cell viability, but decreased SA- $\beta$-gal positive cells and partially reversed the effects of the miR-20b inhibitor and $\mathrm{H}_{2} \mathrm{O}_{2}$ on endothelial cells. Senescent cells are typically characterized by increased expression of cell cell-cycle inhibitors (such as p21 and/or p16), senescence-associated secretion phenotype, DNA damage and induced SA- $\beta$-gal activity (41). The senescence markers p16 and p21 play a regulatory role in the process of cell senescence, and can mediate cell cycle arrest and reduce the accumulation of damaged DNA $(42,43)$. RT-qPCR data revealed that the levels of p16 and p21 were downregulated by siTXNIP, and that low level of TXNIP could partially reverse the senescence of endothelial cell induced by miR-20b inhibitor and $\mathrm{H}_{2} \mathrm{O}_{2}$.

Endothelial dysfunction is associated with the activation of the TXNIP/NLRP3 inflammasome axis (44). TXNIP plays a critical role in redox regulation, cell growth and other pathways, moreover, the increased expression of TXNIP leads to cell senescence of endothelial cells (45). The NLRP3 inflammasome is involved in the mechanism of cells senescence (46). TXNIP can bind to NLRP3 under oxidative stress, thereby activating the NLRP3 inflammasome (47). The activated NLRP3 inflammasome can further activate Caspase-1, while the activated Caspase-1 increases the expression of pro-inflammatory cytokines and promotes inflammation response and oxidative stress, therefore inducing endothelial cell senescence $(48,49)$. In the current study, siTXNIP reduced the expression of TXNIP, NLRP3 and cleaved Caspase-1. The results reveal that siTXNIP inhibits the activation of the NLRP3 inflammasome and Caspase-1, reduces oxidative stress and reverses the cell senescence induced by oxidative stress.

The Wnt/ $\beta$-catenin pathway is an important pathway that regulates the biological behavior of cells and plays different roles in diverse tissues and diseases (50). Some studies revealed that the excessive activation of the $\mathrm{Wnt} / \beta$-catenin 
signaling pathway is associated with cellular senescence and that the p53/p21 pathway is the main mediator in cell senescence induced via $\mathrm{Wnt} / \beta$-catenin pathway $(51,52)$. In this study, siTXNIP was found to inhibit Wnt/ $\beta$-catenin pathway and the present study speculated that TXNIP mainly regulate cell senescence via regulating the $\mathrm{Wnt} / \beta$-catenin pathway. Moreover, a relatively slight decrease of cleaved Caspase-1 was observed compared with the change in TXNIP and NLRP3. A previous study indicated that the PI3K pathway is also involved in the activation of cleaved Caspase-1 and the present study inferred that TXNIP and NLRP3 regulate the activation of cleaved-Caspase 1 ; however, it is not the only pathway involved in activating cleaved-Caspase 1 in senescent HUVECs. In addition, as the interleukin (IL)- $1 \beta$ precursor is cleaved by cleaved-Caspase 1 , further experiments should be performed to determine the level of IL-1 $\beta$ in HUVECs. Additionally, experiments in animals should be performed to confirm the present conclusion.

In conclusion, the present study demonstrated high expression of miR-20b promotes cell viability and inhibits cell senescence induced by oxidative stress. TXNIP is a direct target gene for miR-20b, and silencing of TXNIP enhances cell viability, reduces the expression of cell-senescence related genes and inhibits the $\mathrm{Wnt} / \beta$-catenin pathway. The high expression of miR-20b inhibits endothelial cell senescence, which is possibly realized through regulating the TXNIP/NLRP3 axis to inhibit the Wnt/ $\beta$-catenin pathway.

\section{Acknowledgements}

Not applicable.

\section{Funding}

No funding was received.

\section{Availability of data and materials}

The analyzed data sets generated during the present study are available from the corresponding author upon reasonable request.

\section{Authors' contributions}

Substantial contributions to conception and design: FD and $\mathrm{XZ}$, Data acquisition, data analysis and interpretation: SD, YL, KW and YQ, Drafting the article or critically revising it for important intellectual content: FD and XZ. Final approval of the version to be published: All authors. Agreement to be accountable for all aspects of the work in ensuring that questions related to the accuracy or integrity of the work are appropriately investigated and resolved: All authors.

\section{Ethics approval and consent to participate}

Not applicable.

\section{Patient consent for publication}

Not applicable.

\section{Competing interests}

The authors declare that they have no competing interests.

\section{References}

1. Mitchell SJ, Scheibye-Knudsen M, Longo DL and de Cabo R: Animal models of aging research: Implications for human aging and age-related diseases. Annu Rev Anim Biosci 3: 283-303, 2015.

2. Wu IC, Lin CC and Hsiung CA: Emerging roles of frailty and inflammaging in risk assessment of age-related chronic diseases in older adults: The intersection between aging biology and personalized medicine. Biomedicine (Taipei) 5: 1, 2015.

3. Thijssen DH, Carter SE and Green DJ: Arterial structure and function in vascular ageing: Are you as old as your arteries? J Physiol 594: 2275-2284, 2016.

4. Maeda M, Hayashi T, Mizuno N, Hattori Y and Kuzuya M: Intermittent high glucose implements stress-induced senescence in human vascular endothelial cells: Role of superoxide production by NADPH oxidase. PLoS One 10: e0123169, 2015.

5. Su JB: Vascular endothelial dysfunction and pharmacological treatment. World J Cardiol 7: 719-741, 2015.

6. Donato AJ, Morgan RG, Walker AE and Lesniewski LA: Cellular and molecular biology of aging endothelial cells. J Mol Cell Cardiol 89: 122-135, 2015.

7. Yang S, Mi X, Chen Y, Feng C, Hou Z, Hui R and Zhang W: MicroRNA-216a induces endothelial senescence and inflammation via Smad3/IKB $\alpha$ pathway. J Cell Mol Med 22: 2739-2749, 2018.

8. Gao Q, Chen K, Gao L,Zheng Y and Yang YG: Thrombospondin-1 signaling through CD47 inhibits cell cycle progression and induces senescence in endothelial cells. Cell Death Dis 7: e2368, 2016.

9. Dangwal $\mathrm{S}$ and Thum T: microRNA therapeutics in cardiovascular disease models. Annu Rev Pharmacol Toxicol 54: 185-203, 2014.

10. Xue Y, Wei Z, Ding H, Wang Q, Zhou Z, Zheng S, Zhang Y, Hou D, Liu Y, Zen K, et al: MicroRNA-19b/221/222 induces endothelial cell dysfunction via suppression of PGC- $1 \alpha$ in the progression of atherosclerosis. Atherosclerosis 241: 671-681, 2015.

11. Liu CW, Sung HC, Lin SR, Wu CW, Lee CW, Lee IT, Yang YF, Yu IS, Lin SW, Chiang MH, et al: Resveratrol attenuates ICAM-1 expression and monocyte adhesiveness to TNF- $\alpha$-treated endothelial cells: Evidence for an anti-inflammatory cascade mediated by the miR-221/222/AMPK/p38/NF-кB pathway. Sci Rep 7: 44689, 2017.

12. Schober A, Nazari-Jahantigh M, Wei Y, Bidzhekov K, Gremse F, Grommes J, Megens RT, Heyll K, Noels H, Hristov M, et al: MicroRNA-126-5p promotes endothelial proliferation and limits atherosclerosis by suppressing Dlk1. Nat Med 20: 368-376, 2014.

13. Xiao D, Hu Y, Fu Y, Wang R, Zhang H, Li M, Li Z, Zhang Y, Xuan L, Li X, et al: Emodin improves glucose metabolism by targeting microRNA-20b in insulin-resistant skeletal muscle. Phytomedicine 59: 152758, 2019.

14. Yamakuchi $M$ and Hashiguchi T: Endothelial cell aging: How miRNAs contribute? J Clin Med 7: pii: E170, 2018.

15. Livak KJ and Schmittgen TD: Analysis of relative gene expression data using real-time quantitative PCR and the 2(-Delta Delta C(T)) method. Methods 25: 402-408, 2001.

16. Lin YJ, Zhen YZ, Wei J, Liu B, Yu ZY and Hu G: Effects of Rhein lysinate on $\mathrm{H} 2 \mathrm{O} 2$-induced cellular senescence of human umbilical vascular endothelial cells. Acta Pharmacol Sin 32: 1246-1252, 2011

17. Mitsumoto A, Takanezawa Y, Okawa K, Iwamatsu A and Nakagawa Y: Variants of peroxiredoxins expression in response to hydroperoxide stress. Free Radic Biol Med 30: 625-635, 2001.

18. Bulterijs S, Hull RS, Björk VC and Roy AG: It is time to classify biological aging as a disease. Front Genet 6: 205, 2015.

19. Gems D: The aging-disease false dichotomy: Understanding senescence as pathology. Front Genet 6: 212, 2015.

20. Ogrodnik M, Miwa S, Tchkonia T, Tiniakos D, Wilson CL, Lahat A, Day CP, Burt A, Palmer A, Anstee QM, et al: Cellular senescence drives age-dependent hepatic steatosis. Nat Commun 8: 15691, 2017.

21. Childs BG, Durik M, Baker DJ and van Deursen JM: Cellular senescence in aging and age-related disease: From mechanisms to therapy. Nat Med 21: 1424-1435, 2015. 
22. Garrido AM and Bennett M: Assessment and consequences of cell senescence in atherosclerosis. Curr Opin Lipidol 27: 431-438, 2016

23. Fan LM, Douglas G, Bendall JK, McNeill E, Crabtree MJ, Hale AB, Mai A, Li JM, McAteer MA, Schneider JE, et al: Endothelial cell-specific reactive oxygen species production increases susceptibility to aortic dissection. Circulation 129: 2661-2672, 2014

24. Katsuumi G, Shimizu I, Yoshida Y and Minamino T: Vascular senescence in cardiovascular and metabolic diseases. Front Cardiovasc Med 5: 18, 2018.

25. Liu Y, Bloom SI and Donato AJ: The role of senescence, telomere dysfunction and shelterin in vascular aging. Microcirculation 26: e12487, 2019.

26. Conti V, Corbi G, Simeon V, Russomanno G, Manzo V, Ferrara N and Filippelli A: Aging-related changes in oxidative stress response of human endothelial cells. Aging Clin Exp Res 27: 547-553, 2015

27. Liu R, Liu H, Ha Y, Tilton RG and Zhang W: Oxidative stress induces endothelial cell senescence via downregulation of Sirt6. Biomed Res Int 2014: 902842, 2014.

28. Mistriotis P and Andreadis ST: Vascular aging: Molecular mechanisms and potential treatments for vascular rejuvenation. Ageing Res Rev 37: 94-116, 2017.

29. Crowe EP, Tuzer F, Gregory BD, Donahue G, Gosai SJ, Cohen J, Leung YY, Yetkin E, Nativio R, Wang LS, et al: Changes in the transcriptome of human astrocytes accompanying oxidative stress-induced senescence. Front Aging Neurosci 8: 208, 2016.

30. Bu H, Wedel S, Cavinato $\mathrm{M}$ and Jansen-Dürr P: MicroRNA regulation of oxidative stress-induced cellular senescence. Oxid Med Cell Longev 2017: 2398696, 2017.

31. Lou J, Wang Y, Zhang Z and Qiu W: MiR-20b inhibits mycobacterium tuberculosis induced inflammation in the lung of mice through targeting NLRP3. Exp Cell Res 358: 120-128, 2017.

32. Wong PF, Jamal J, Tong KL, Khor ES, Yeap CE, Jong HL, Lee ST, Mustafa MR, Abubakar S: Deregulation of hsa-miR-20b expression in TNF- $\alpha$-induced premature senescence of human pulmonary microvascular endothelial cells. Microvasc Res 114 26-33, 2017.

33. Guo D, Ye Y, Qi J, Tan X, Zhang Y, Ma Y and Li Y: Age and sex differences in microRNAs expression during the process of thymus aging. Acta Biochim Biophys Sin (Shanghai) 49: 409-419, 2017.

34. Greussing R, Hackl M, Charoentong P, Pauck A, Monteforte R, Cavinato $M$, Hofer $E$, Scheideler $M$, Neuhaus $M$, Micutkova L, et al: Identification of microRNA-mRNA functional interactions in UVB-induced senescence of human diploid fibroblasts. BMC Genomic 14: 224, 2013.

35. Tang B, Bao N, He G and Wang J: Long noncoding RNA HOTAIR regulates autophagy via the miR-20b-5p/ATG7 axis in hepatic ischemia/reperfusion injury. Gene 686: 56-62, 2019.

36. Ao X, Nie P, Wu B, Xu W, Zhang T, Wang S, Chang H and Zou Z: Decreased expression of microRNA-17 and microRNA-20b promotes breast cancer resistance to taxol therapy by upregulation of NCOA3. Cell Death Dis 7: e2463, 2016.

37. Zhang M, Jiang Y, Guo X, Zhang B, Wu J, Sun J, Liang H, Shan H, Zhang Y, Liu J, et al: Long non-coding RNA cardiac hypertrophy-associated regulator governs cardiac hypertrophy via regulating miR-20b and the downstream PTEN/AKT pathway. J Cell Mol Med 23: 7685-7698, 2019.

38. Katayama M, Wiklander OPB, Fritz T, Caidahl K, El-Andaloussi S, Zierath JR and Krook A: Circulating exosomal miR-20b-5p is elevated in type 2 diabetes and could impair insulin action in human skeletal muscle. Diabetes 68: 515-526, 2019.

39. Xiao X, Chen C, Guo P, Zhang T, Fischbach S, Fusco J, Shiota C Prasadan K, Dong H and Gittes GK: Forkhead box protein 1 (FoxO1) inhibits accelerated $\beta$ cell aging in pancreas-specific SMAD7 mutant mice. J Biol Chem 292: 3456-3465, 2017.
40. Kandhaya-Pillai R, Miro-Mur F, Alijotas-Reig J, Tchkonia T, Kirkland JL and Schwartz S: TNF $\alpha$-senescence initiates a STAT-dependent positive feedback loop, leading to a sustained interferon signature, DNA damage, and cytokine secretion. Aging (Albany NY) 9: 2411-2435, 2017.

41. Wu Q, Jiang D, Matsuda JL, Ternyak K, Zhang B and Chu HW: Cigarette smoke induces human airway epithelial senescence via growth differentiation factor 15 production. Am J Respir Cell Mol Biol 55: 429-438, 2016

42. Jin H, Lian N, Bian M, Zhang C, Chen X, Shao J, Wu L, Chen A, Guo Q, Zhang F and Zheng S: Oroxylin A inhibits ethanol-induced hepatocyte senescence via YAP pathway. Cell Prolif 51: e12431, 2018.

43. Khan SY, Awad EM, Oszwald A, Mayr M, Yin X, Waltenberger B, Stuppner H, Lipovac M, Uhrin P and Breuss JM: Premature senescence of endothelial cells upon chronic exposure to $\mathrm{TNF}$ can be prevented by N-acetyl cysteine and plumericin. Sci Rep 7: 39501, 2017.

44. Li Y, Yang J, Chen MH, Wang Q, Qin MJ, Zhang T, Chen XQ, Liu BL and Wen XD: Ilexgenin A inhibits endoplasmic reticulum stress and ameliorates endothelial dysfunction via suppression of TXNIP/NLRP3 inflammasome activation in an AMPK dependent manner. Pharmacol Res 99: 101-115, 2015.

45. Riahi Y, Kaiser N, Cohen G, Abd-Elrahman I, Blum G, Shapira OM, Koler T, Simionescu M, Sima AV, Zarkovic N, et al: Foam cell-derived 4-hydroxynonenal induces endothelial cell senescence in a TXNIP-dependent manner. J Cell Mol Med 19: 1887-1899, 2015.

46. Yin Y, Zhou Z, Liu W, Chang Q, Sun G and Dai Y: Vascular endothelial cells senescence is associated with NOD-like receptor family pyrin domain-containing 3 (NLRP3) inflammasome activation via reactive oxygen species (ROS)/thioredoxin-interacting protein (TXNIP) pathway. Int J Biochem Cell Biol 84: 22-34, 2017.

47. Sun X, Jiao X, Ma Y, Liu Y, Zhang L, He Y and Chen Y: Trimethylamine N-oxide induces inflammation and endothelial dysfunction in human umbilical vein endothelial cells via activating ROS-TXNIP-NLRP3 inflammasome. Biochem Biophys Res Commun 481: 63-70, 2016.

48. Spadaro O, Goldberg EL, Camell CD, Youm YH, Kopchick JJ, Nguyen KY, Bartke A, Sun LY and Dixit VD: Growth hormone receptor deficiency protects against age-related NLRP3 inflammasome activation and immune senescence. Cell Rep 14: 1571-1580, 2016.

49. He B, Zhang B, Wu F, Wang L, Shi X, Qin W, Lin Y, Ma S and Liang J: Homoplantaginin inhibits palmitic acid-induced endothelial cells inflammation by suppressing TLR4 and NLRP3 inflammasome. J Cardiovasc Pharmacol 67: 93-101, 2016.

50. Nusse R and Clevers $\mathrm{H}$ : Wnt/ $/$-catenin signaling, disease, and emerging therapeutic modalities. Cell 169: 985-999, 2017.

51. Zhang DY, Wang HJ and Tan YZ: Wnt/ $\beta$-catenin signaling induces the aging of mesenchymal stem cells through the DNA damage response and the p53/p21 pathway. PLoS One 6: e21397, 2011.

52. Chen J, Jia YS, Liu GZ, Sun Q,Zhang F, Ma S and Wang YJ: Role of LncRNA TUG1 in intervertebral disc degeneration and nucleus pulposus cells via regulating Wnt/ $\beta$-catenin signaling pathway. Biochem Biophys Res Commun 491: 668-674, 2017.

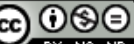

This work is licensed under a Creative Commons Attribution-NonCommercial-NoDerivatives 4.0 International (CC BY-NC-ND 4.0) License. 